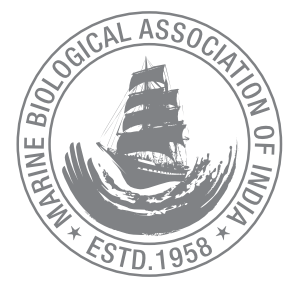

\title{
First distributional report of Filinia camasecla Myers, 1938 (Rotifera: Eurotatoria: Monogononta) from peninsular India
}

\author{
Asha Ravi ${ }^{1,2 *}$, K. R. Aju', Molly Varghese ${ }^{1}$ and K. K. Joshi ${ }^{1}$ \\ ${ }^{1}$ ICAR-Central Marine Fisheries Research Institute, Kochi- 682018, Kerala, India. \\ ${ }^{2}$ Cochin University of Science and Technology, Kochi-22, Kerala, India. \\ *Correspondence e-mail: ashamply@gmail.com
}

Received: 10 July 2020 Accepted: 25 July 2020 Published: 30 July 2020

Short communication

\begin{abstract}
This work reports the first distributional record of Filinia camasecla Myers, 1938 in south India from the Cochin backwaters on the northern stretch of Lake Vembanad. Earlier, the distribution of this species has been known from Oriental (South East-Asia) and Neotropical biogeographical realms. Though it comes under the oriental endemics no previous records of this species were available from this area or other parts of Vembanad backwaters. The occurrence of $F$. camasecla in this additional geographic region highlights the range extension of the species.
\end{abstract}

Keywords: Filinia camasecla, Lake Vembanad, rotifers, distribution

\section{Introduction}

Rotifers are the primary freshwater invertebrates which play a pivotal role in many freshwater ecosystems (Segers, 2008). Their diversity and distribution is primarily influenced by water quality and by eutrophication and salinization (Kumar and Kiran, 2015). An account of the global diversity of rotifers in freshwater as by Segers (2008) noted that most studies regarding the distribution of rotifers were carried out in Palearctic and Nearctic realms. Filinia camasecla which is considered a common oriental species (Segers, 2008) was first described by Myers from a lake in the Panama Canal area (Berzin, 1973) in 1938. Sudzuki (1989) treated it under a different genus Parafilinia camasecla. Myers had included this species in the family Testudinellidae but later, taxonomists, placed it in the family Trochosphaeridae. On the southwest coast of India where a large number of annual and perennial rivers and brackish water systems exist, quite a few studies were conducted to date regarding the diversity and distribution of the rotifer fauna. F. camasecla (Family Trochosphaeridae) is a common oriental species (Sharma, 2014) and its occurrence has been reported earlier only from the north-eastern part of India. Studies on rotifers from peninsular India, however, lack the record of this species. This study reports the first occurrence of $F$ camasecla from peninsular India.

\section{Material and methods}

Individuals of $F$. camasecla were observed in the plankton samples collected from Kottappuram on the northern part of Cochin backwaters during December 2018 and from Mulavukad, towards the southern part of the backwaters during September 2019 (Fig.1). The collected samples were preserved in $4 \%$ formalin. 
The identification of the collected samples was done following Myers (1938), Segers (2008), Sharma and Sharma (2005), Sharma (2014) and Koste (2012). The microscopic images of the specimens were taken with a magnification of $40 \mathrm{x}$.

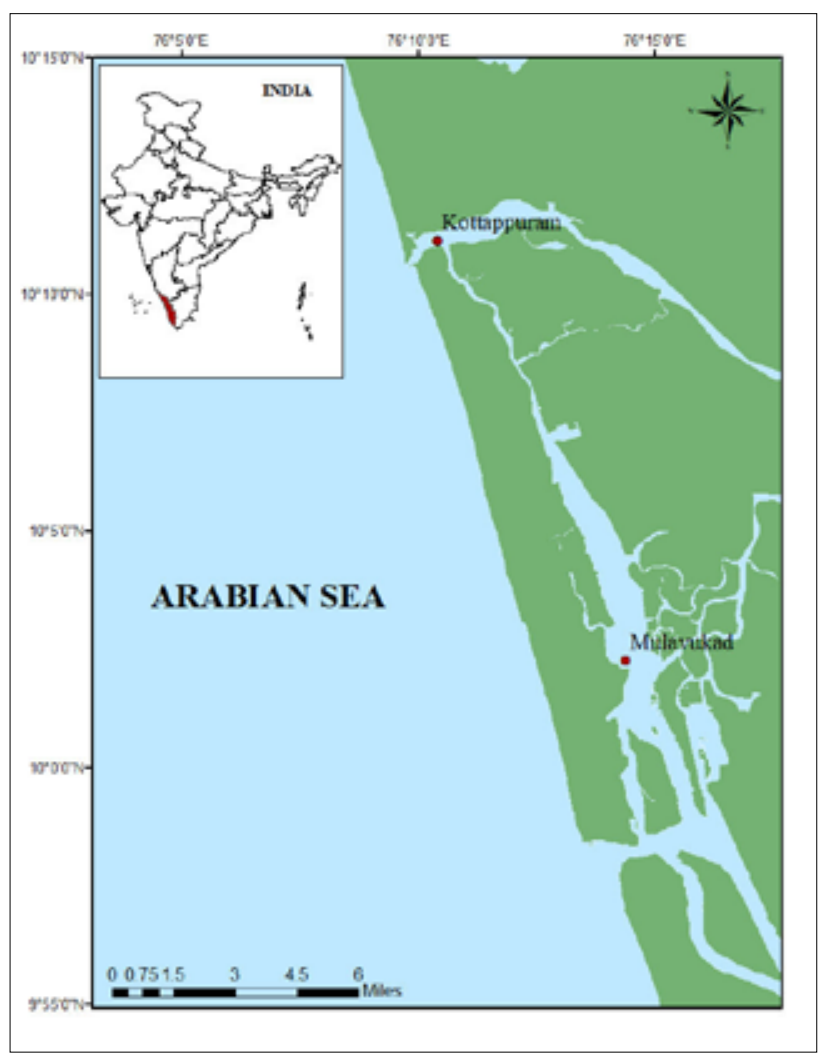

Fig. 1. Map showing the study areas

\section{Results and discussion}

\section{Systematics}

$\begin{array}{ll}\text { Class } & \text { :Eurotatoria } \\ \text { Subclass } & \text { :Monogononta } \\ \text { Super Order } & \text { :Gnesiotrocha } \\ \text { Order } & \text { :Flosculariaceae } \\ \text { Family } & \text { :Trochosphaeridae Harring, } 1913 \\ \text { Genus } & \text { :Filinia Bory de St. Vincent, } 1824\end{array}$

Filinia camasecla Myers, 1938

Synonym :Filinia camasecla cambodgensis Berzins, 1973 Locality :Cochin backwaters (Kottappuram and Mulavukad), Kerala, India.

\section{Description}

The morphometrics of both the specimens was recorded and found significant variation in the length of lorica and lateral spine (Table 1). The most important feature that distinguishes the species is the presence of two lateral spines and a posterior spine (Fig. 2). The lateral spines are longer than the lorica. The morphometry of the specimen collected during December 2018 and September 2019 was found to match with the ranges given by Zhdanova (2011) except for the lorica length of the September 2019 specimen and posterior spine length of both specimens. In this case, the lorica length was greater than the range given by Zhdanova, while the posterior spine length was below that range.

Table 1. Morphometric measurements of the present study specimens compared with the specimens of other workers.

\begin{tabular}{lllll}
\hline $\begin{array}{l}\text { Measurement. } \\
\text { Sample }\end{array}$ & Dec (2018) & Sep (2019) & Myers, 1938 & $\begin{array}{l}\text { Zhdanova, } \\
2011\end{array}$ \\
\hline Lorica length $(\mu \mathrm{m})$ & 89.86 & 177.19 & 84 & $87-109$ \\
\hline Lorica width $(\mu \mathrm{m})$ & 83.86 & 77.98 & 78 & $78-92$ \\
\hline Lateral spine $(\mu \mathrm{m})$ & 70.67 & 105.37 & 86 & $70-112$ \\
\hline Posterior spine $(\mu \mathrm{m})$ & 82.70 & 70.5 & 90 & $84-118$
\end{tabular}

\section{Distribution}

F. camasecla is so far recorded from Panama (Myers, 1938), the northeastern part of India (Sharma and Sharma, 2005; Sharma, 2014), Central Vietnam (Zhdanova, 2011), Sri Lanka (Chengalath et al., 1973), Indonesia (Koste, 2012) and it has several records in the Mekong River Basin and Combodia (Meas and Sanoamuang, 2008); in the fresh water bodies of Thailand (Chittapun et al., 2009, Sanoamuang et al., 1995; Segers, 2008), China (Xin-Li et al., 2004; Zhuge et al., 1998) and Singapore (Sudzuki, 1991).

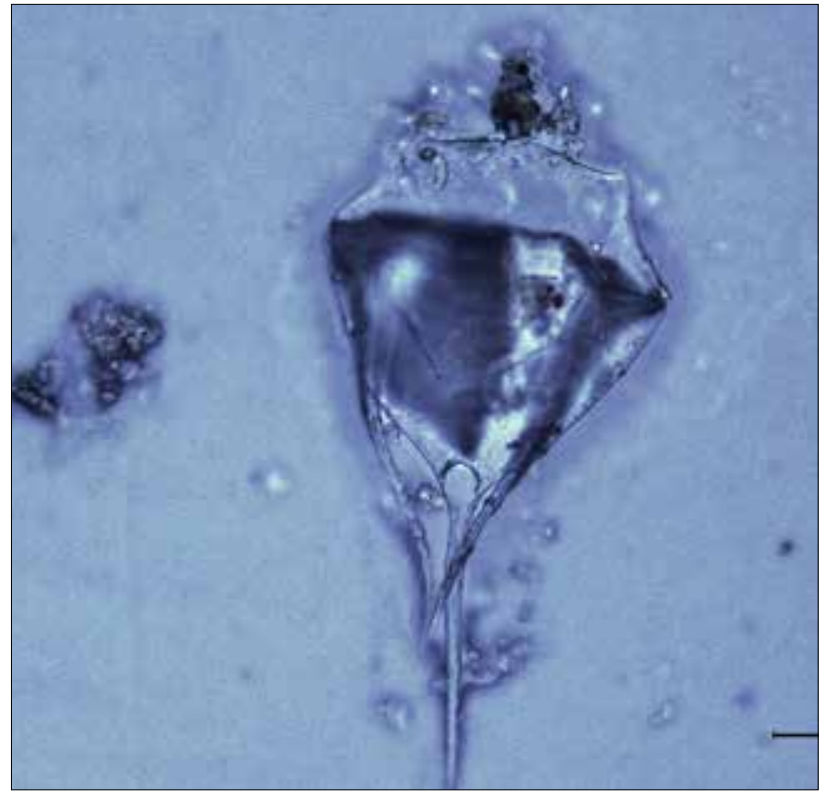

Fig. 2. F. camasecla collected during September 2019 from Cochin backwater 
Filinia camasecla were collected for the first time (December 2018) from the lower reaches of River Periyar (Kottapuram), near Azhikodu barmouth in the Arabian Sea. Later it was recorded (September 2019) near Cochin barmouth (Mulavukad). The salinity of these two stations was $8 \mathrm{ppt}$ and 0 ppt respectively at the time of observations (post- monsoon) as the hydrographic parameters of these regions are greatly under the influence of monsoonal and tidal effects. Being primarily a fresh water inhabitant, the infrequent occurrence of the species in a brackish water lagoon is clearly by way of the river discharge which is especially enormous during and after the monsoons. In spite of the several studies in planktons that are being conducted in this region, the absence of this species in the samples clearly points to its scarce and isolated distribution.

\section{Acknowledgements}

The authors are thankful to Dr. A. Gopalakrishanan, Director, ICAR- CMFRI for the facilities provided. Special thanks to Shri. K. M. Sreekumar for the active support during the sample collection. The first author also thank the University Grants Commission, New Delhi for their financial assistance.

\section{References}

Berzins, B. 1973. Some rotifers from Cambodia. Hydrobiologia, 41(4):453-459. Chengalath, R., C. H. Fernando and W. Koste. 1973. Rotifera from Sri Lanka (Ceylon)
2. Further studies on the Eurotatoria including new records. Bull. Fish. Res. Stn. Sri Lanka (Ceylon), 24(1-2): 29-62.

Chittapun, S., P. Pholpunthin and L.O. Sanoamuang. 2009. Diversity and composition of zooplankton in rice fields during a crop cycle at Pathum Thani province, Thailand. Songklanakarin. J. Sci. Techno., 31(3):261-267.

Koste, W. 2012. Rotatorien aus Gewässern am Mittleren Sungai Mahakam, einem Überschwemmungsgebiet in E-Kalimantan, Indonesian Borneo.

Kumar, K. H. and B. R. Kiran. 2015. Population dynamics of Rotifers in Jannapura tank, Karnataka. Int. J. Fish. Aquatic. Stud., 3(1):165-168.

Myers, F. J. 1938. New species of Rotifera from the collection of the American Museum of Natural History. Am. Mus. Novit. no.1011.

Meas, S. and L.O. Sanoamuang. 2008. Rotifer Communities in the Cambodian Mekong River Basins. KKU Res. J., 8(2):18-30.

Sudzuki, M. 1989. Rotifera from the Oriental region and their characteristics. Special Issue celebrating the centennial anniversary of the foundation of Nihon Daigaku University, Tokyo, 3: 325-366.

Sudzuki, M. 1991. The rotifera from Singapore and Taiwan. In Proceedings of the Japanese Society of Systematic Zoology, 43: 1-34.

Sanoamuang, L. O., H. Segers and H. J. Dumont. 1995. Additions to the rotifer fauna of south-east Asia: new and rare species from north-east Thailand. Hydrobiologia, 313(1):35-45.

Segers, H. 2008. Global Diversity of Rotifers (Rotifera) in Freshwater, Hydrobiologia, 595: 49-59.

Sharma, B. K. 2014. Rotifers (Rotifera: Eurotatoria) from wetlands of Majuli-the largest river island, the Brahmaputra river basin of upper Assam, northeast India. Check List, 10(2): 292-298.

Sharma, B. K. and S. Sharma. 2005. Faunal diversity of rotifers (rotifera: eurotatoria) of deepor beel, assam (northeast india)-a Ramsar site. J. Bombay. Nat. Hist. Soc., 102(2): 169.

Xin-Li, W., X. Yi-Long, Z. Lei, L. Xing-Jia, and C. Fa-Yang. 2004. Community structure and species diversity of rotifers in the Wuhu section of the Qingyi River. Biodivers. J., 12(4): 387-395

Zhuge, Y., X. Huang and W. Koste. 1998. Rotifera recorded from China, 1893-1997, with remarks on their composition and distribution. Int. Rev. Hydrobiol., 83(3): 217-232.

Zhdanova, S. M. 2011. The species composition of rotifers in the water reservoirs of Central Vietnam. Inland. Water. Biol., 4(4): 425-434. 